\title{
THE \&FFECT OF THE NEW REVENUE STANDARD ON CLIENT LOYALTY PROGRAMMES
}

\author{
Sophia Brink* \\ Universiteit Stellenbosch \\ sophiabrink@sun.ac.za
}

Received: August 2013

Accepted: February 2014

\begin{abstract}
The popularity of client loyalty programmes has increased drastically over the past few years, with more than 100 suppliers in South Africa currently making use of them. On 1 July 2007 the IASB issued IFRIC 13 to give specific guidance to suppliers on the accounting treatment of client loyalty programme transactions. In the process of compiling a new revenue standard, the International Accounting Standard Board published Exposure Draft ED/2011/6 Revenue from Contracts with Customers on 14 November 2011 to supersede virtually all existing revenue standards and interpretations under IFRS, including IFRIC 13. Although the effective date of the new revenue standard is 1 January 2017, in view of the nature of a client loyalty programme transaction it would be prudent for suppliers to start collecting data immediately for the retrospective application. Given the time limit and the minimal specific reference to client loyalty programme transactions in the proposed new model, the main aim of the research was to investigate the proposed new model's impact on the accounting treatment of client loyalty programme transactions. The similarities and differences between the guidelines in IFRIC 13 and those of the proposed new model as well as the specific paragraphs in the proposed new model that are applicable to client loyalty programme transactions were considered. A specific recognition difference and a presentation difference has been identified between the accounting treatment of a client loyalty programme transaction under IFRIC 13 and that of the proposed new model.
\end{abstract}

Keywords

Client loyalty programmes, IFRIC 13, عD/2011/6, new revenue standard.

*Ms S Brink is a senior lecturer in the School of Accountancy, Stellenbosch University, South Africa. 


\section{BACKGROUND AND FORMULATION OF THE STUDY}

\subsection{Background}

A client loyalty programme can be defined as a programme where consumers accumulate free points or miles based on the purchases of goods or services from a supplier. The consumer can exchange these points or miles for a variety of commodities (including goods, services or a discount on a next purchase transaction) at a supplier (Liu, 2007:20). The popularity of client loyalty programmes has increased drastically (Travel wires, 2011), and more than 100 suppliers in South Africa are already making use of these programmes (Conradie, 2011). On 1 July 2007 the International Accounting Standards Board (IASB) issued IFRIC 13 (the Interpretation of International Financial Reporting Interpretation Committee 13) to give specific guidance to suppliers on the accounting treatment of client loyalty programme transactions. This Interpretation has been applied by suppliers with annual periods beginning on or after 1 July 2008.

On 14 November 2011 the IASB, together with the United States Financial Accounting Standards Board (FASB), published Exposure Draft ED/2011/6 Revenue from Contracts with Customers (ED) to supersede virtually all existing revenue standards and interpretations under IFRS and US GAAP (Deloitte, 2012:1; Ernst \& Young, 2012b:2). The IASB and FASB designed the proposed standard to streamline accounting for revenue across all industries and to correct inconsistencies in existing standards and practices (Lamoreaux, 2012:30). The proposed standard is intended to replace IAS 11 Construction Contracts, IAS 18 Revenue, IFRIC 13 Customer Loyalty Programmes, IFRIC 15 Agreements for the Construction of Real Estate, IFRIC 18 Transfers of Assets from Customers and SIC 31 Revenue - Barter Transactions Involving Advertising Services (KPMG, 2011:4).

The process of compiling a new revenue standard started in 2010 with the issue of $\varepsilon D / 2010 / 6$ Revenue from Contracts with Customers and, based on comments received, significant changes were made to the proposed model. The exposure draft was issued for a second time and the more than 300 comment letters (Deloitte, 2012:1) that were received by 13 March 2012 (Ernst \& Young, 2011:1) are currently under consideration.

Redeliberations on the second exposure draft continued throughout 2012 and 2013 with substantial redeliberations expected to be complete in 2014 and a final standard to be issued in the first quarter of 2014 (IASB, 2014). The boards decided that the new revenue standard will be effective for annual periods beginning on or after 1 January 2017 (Seghposs, 2013). The final standard would be applied retrospectively for all periods presented in the period of adoption with only limited reliefs. Early adoption of the final standard will not be permitted by the IASB and the FASB (Seghposs, 2013). First-time IFRS adopters are able to utilise the same transition relief as existing users of IFRS (KPMG, 2011:2).

\subsection{Research problem}

For annual reporting periods beginning on or after 1 January 2017, all client loyalty programme suppliers could be required to account for transactions applying the new revenue standard. After two rounds of public consultation on the ED Revenue from Contracts with Customers, the new revenue standard will in all probability be in line with the current $\varepsilon D / 2011 / 6$. FASB member Daryl Buck said that the FASB and IASB have received 'widespread acceptance on the direction' of their latest proposal on revenue recognition (Marcy, 2012:535). Buck also highlighted the 
'drastic reduction' in the number of comment letters received on the revised revenue recognition proposal compared with the first one (from nearly a 1000 comment letters in 2010 to only 300 comment letters in 2012). According to Buck, this indicates that it addressed most of the major concerns of the first effort (Marcy, 2012:535). Peter Margaritas, an IFRS expert, commented that it appears as if the boards have tried to address all comments in the 2011 ED and that it is unlikely that there will be many significant changes between the present proposed model and the final standard (Lamoreaux, 2012:30).

This new revenue standard will replace IFRIC 13, an interpretation client loyalty programme suppliers would have applied for nine years up until the effective date of the new proposed revenue standard. The single proposed new revenue standard is replacing six existing standards or interpretations. According to the proposals, all entities would apply the single model under the new revenue standard. A greater degree of judgement would be required, thus increasing the challenge of consistent interpretation by preparers (KPMG, 2011:1). It is uncertain whether or not the current proposals are sufficiently clear to be successfully applied. The proposals may not affect all entities, but it is likely that certain entities would experience significant change (KPMG, 2011:1). The initial effective date of 1 January 2015 (ED/2011/6, par. IN35) was extended to 1 January 2017 (Ernst \& Young, 2013). The significant delay between the issuing of the new standard (expected in the first quarter of 2014) and the effective date is intended to provide entities with adequate time to prepare for the adoption of the new standard (Ernst \& young, 2013). This highlights the drastic changes that can be expected. The boards also indicated the importance of entities accumulating adequate transition information on a realtime basis during the extended transition period (Ernst \& Young, 2013).

Since the new revenue standard is applicable to a wide variety of transactions and is not as specific as IFRIC 13, there is a risk that client loyalty programme suppliers will continue to apply the principles of IFRIC 13. The ED/2011/6 refers only once to customer award credits (points) in the Application Guidance (Appendix B) paragraph B20 and the illustrative examples that accompany the $\varepsilon D$ only include one client loyalty programme transaction example. With minimal specific guidelines it is clear that client loyalty programme suppliers will have difficulty in transitioning and applying this proposed new model. 1 January 2017 (the effective date of the new revenue standard) might seem far off in the future and the risk exists that client loyalty programme suppliers might delay familiarising themselves with the new revenue standard. Due to the nature of a client loyalty programme transaction (especially programmes where the points or miles are not subject to an expiry date), transactions today can have an impact on reporting in 2017 .

\subsection{Research objective and methodology}

The main aim of the research was to determine the impact of the $\varepsilon D / 2011 / 6$ on the accounting treatment of client loyalty programme transactions. In order to achieve this aim, the following research questions were addressed:

- What are the similarities and differences between the guidelines in IFRIC 13 and those in the proposed new model?

- What paragraphs in the proposed new model are applicable to client loyalty programme transactions?

- Are there any additional disclosure requirements applicable to client loyalty programme transactions? 
This study focuses on single-company programmes only, as this was an initial study and the scope of the study would otherwise be too wide. Another reason for this decision was that single-company programmes are the simplest form of client loyalty programmes. In the South African market single-company programmes are also the most popular client loyalty programmes with reference to known active membership numbers (Conradie, 2007:135-235). The only example included in the illustrative examples that accompany $\varepsilon D / 2011 / 6$ is an illustration of a single-company client loyalty programme transaction. The scope of this research was therefore limited to single-company programmes. The other two categories of client loyalty programmes (single-company-dominated programmes and multi-partner programmes) were therefore not considered in this research.

The starting point in determining the impact of the proposed new model on client loyalty programme transactions was to establish the similarities and the differences between the proposed new model and the current practice under IFRIC 13. In order to determine the similarities and the differences between IFRIC 13 and the proposed new model, both IFRIC 13 and the proposed model needed to be investigated and then compared.

In order to determine which paragraphs of the proposed new model are applicable to a singlecompany client loyalty programme transaction, it was important to obtain a better understanding of the functioning of these programmes. Taking into consideration the functioning of single-company client loyalty programmes, the available literature was analysed to determine what the proposed treatment of a single-company client loyalty programme transaction in terms of the proposed new model entails.

\subsection{Research contribution}

In embarking on the study, it was believed that the research would:

- highlight the similarities and the differences between IFRIC 13 and the proposed new model and find out what changes await client loyalty programme suppliers;

- assist client loyalty programme suppliers in the conversion from IFRIC 13 to the proposed new model; and

- highlight which paragraphs in the proposed new model are specifically applicable to client loyalty programme transactions.

\section{THE DEFINITION AND FUNCTIONING OF CLIENT LOYALTY PROGRAMMES}

Section 1 of the Consumer Protection Act No. 68 of 2008 defines the term 'loyalty' as follows (Republic of South Africa, 2008):

... any arrangement or scheme in the ordinary course of business, in terms of which a supplier of goods or services ... offers or grants to a consumer any loyalty credit or award in connection with a transaction or an agreement ...

The basic functioning of client loyalty programmes is as follows: members of the general public can apply for membership by completing an application form where personal information is provided. Approved members will be issued with a membership card that should be scanned during each purchase transaction in order for them to accumulate client loyalty programme points or miles. A magnetic strip on the back of the membership card collects the details of the 
items purchased, together with the points or miles that are granted (Maharaj, 2008:12). The points or miles accumulated on the membership card may later be exchanged for goods, services or a discount on goods or services during a subsequent purchase transaction.

\section{METHOD OF ACCOUNTING}

In order to determine the similarities and differences between IFRIC 13 and the proposed new model, IFRIC 13 and the proposed model needed to be investigated. As a starting point, IFRIC 13 was investigated first, as explained below.

In a client loyalty programme transaction, the supplier grants points to the consumer as part of a normal revenue transaction. These points give the consumer a right to future benefits in the form of goods, services or discounts (benefits). The points granted create the obligation for the supplier to provide future benefits for compensation already received. Thus, the compensation received in the current transaction is for the goods or services delivered in the current transaction and for benefits to be delivered in the future.

In order to account for this compensation, a client loyalty programme supplier currently considers the accounting standard IAS 18 which deals with the accounting treatment of revenue. When dealing specifically with client loyalty programme transactions, IFRIC 13 is also applied.

\subsection{The accounting treatment required by IFRIC 13 (read together with IAS 18)}

IFRIC 13 deals with client loyalty programmes and applies to points that:

- a supplier grants to consumers as part of a revenue transaction; and

- subject to meeting any further qualifying conditions, enables consumers to claim goods or services in the future for free or at a discount (IFRIC 13, par. 3).

The interpretation provides guidance on the accounting treatment of a client loyalty programme transaction by the supplier that grants points to its consumers. Under IFRIC 13 different measurement and recognition requirements exist based on whether the obligation to supply benefits rests on the supplier itself or whether the obligation to supply benefits rests on a third party. The scope of this research was limited to single-company client loyalty programmes. Consequently, client loyalty programmes where the obligation to supply benefits rests on a third party fell outside the scope of this research.

Paragraph 5 of IFRIC 13 states that the supplier must apply paragraph 13 of IAS 18 to recognise the consideration received. Paragraph 13 of IAS 18 states that the accounting treatment in IAS 18 is usually applied separately to each transaction. In certain circumstances it is necessary to apply the accounting treatment to the separately identifiable components of a single transaction in order to reflect the true substance of the transaction. For example, when the selling price of a product includes an identifiable amount for subsequent servicing, that amount is deferred and recognised as revenue over the period during which the service is rendered.

A client loyalty programme transaction may be regarded as a single transaction consisting of two separate identifiable components, namely the sale of goods or services, and the granting of points that gives the consumer a right to benefits. In terms of paragraph 13 , the accounting 
treatment must be applied separately to each of the components in the transaction. The points granted are linked to an identifiable amount or value, i.e. the value of the benefits receivable by the consumer in the future. The selling price therefore includes an identifiable amount for the future supplying of benefits. A client loyalty programme transaction is thus similar to the example referred to in paragraph 13 of IAS 18 (a sales transaction where the selling price includes an amount for subsequent servicing). The consideration received or receivable from the sale should be allocated to the goods or services sold and the points granted. The portion allocated to the goods or services sold will be recognised as revenue during the sales transaction. The portion allocated to the points will be recognised as revenue only when the points are exchanged for benefits, and the recognition of this portion of the revenue is therefore deferred.

Paragraph 5 of IFRIC 13 further states that the fair value of the consideration received or receivable under the initial sale must be allocated between the points and the other components of the sale. Paragraph 6 of IFRIC 13 states that the portion of consideration allocated to the points granted in the underlying sales transaction shall be measured by reference to their fair value.

The Application Guidance to IFRIC 13 (which is considered to be an integral part of the interpretation) provides guidance on determining the fair value. Paragraph 1 of IFRIC 13 Application Guidance (here after referred to as $A G$ ), states that if there is not a quoted market price for an identical point, fair value must be measured using another valuation technique. The supplier may measure the fair value of points with reference to the fair value of the benefits they could be exchanged for; in other words, the value of the points in the hands of the consumer. The fair value of the points takes into account, as appropriate:

- the amount of the discounts or incentives that would otherwise be offered to consumers who have not earned points from an initial sale;

- the proportion of points that are not expected to be exchanged by consumers; and

- non-performance risk (IFRIC 13, AG par. 2).

If consumers can choose from a range of different benefits, the fair value of the points reflects the fair values of the various available benefits, weighted in proportion to the frequency with which each benefit is expected to be selected (IFRIC 13, AG par. 2). In some circumstances, other valuation techniques may be used to determine the fair value. Judgement is required to select and apply the valuation technique that is most appropriate in the circumstances (IFRIC 13, AG par. 3).

Paragraph 7 of IFRIC 13 states that if a supplier supplies the benefits itself, it shall recognise the consideration allocated to points as revenue when points are exchanged and the supplier fulfils its obligation to supply benefits. The amount of revenue recognised shall be based on the number of points that have been exchanged for benefits, relative to the total number expected to be exchanged.

Against the above background of the current practice, the focus of the study could subsequently shift to the proposed new model as contained in $\varepsilon D / 2011 / 6$. 


\section{$3.2 \varepsilon D / 2011 / 6$}

The ED proposes that a single revenue recognition model would apply to all contracts with customers and therefore affects all entities that enter into contracts to provide goods or services to their customers. The ED states that the core principle for revenue recognition is that an 'entity shall recognise revenue to depict the transfer of promised goods and services to customers in an amount that reflects the consideration to which the entity expects to be entitled in exchange for those goods or services' ( $\varepsilon D / 2011 / 6$, par. IN9). This core principle is achieved by the application of the following five sequential steps to recognise revenue:

- Step 1: Identify the contract with a customer.

- Step 2: Identify the separate performance obligations in the contract.

- Step 3: Determine the transaction price.

- Step 4: Allocate the transaction price to the separate performance obligations.

- Step 5: Recognise revenue when (or as) the entity satisfies a performance obligation.

These five steps will assist entities in determining when to recognise revenue and in what amount. Entities are required to exercise a high degree of judgement in applying these five steps. The terms of the contract(s) and all surrounding facts and circumstances, including any implied contractual terms, must be considered. An entity will also have to consistently apply the requirements of the proposed model to contracts with similar characteristics and in similar circumstances (Ernst \& Young, 2012a:3). The model proposes the following two ways to recognise revenue: revenue may be recognised 1 ) over time (similar to current stage of completion accounting) or 2) at a point in time (similar to current sales of goods accounting). Each step of applying the model to a contract is discussed individually below.

\section{Step 1: Identify the contract with a customer}

The aim of step 1 is to identify the contractual rights and obligations to which the revenue recognition model would be applied (Grant Thornton, 2012:14). ED/2011/6 defines a contract as an agreement between two or more parties that creates legally enforceable rights and obligations. Contracts may be oral, written or implied by an entity's customary business practices ( $\varepsilon D / 2011 / 6$, par. 13$)$. A contract must have commercial substance, be appropriately approved, have defined rights for each party and specify the terms and manner of payment for the goods or services to be transferred ( $\varepsilon D / 2011 / 6$, par. 14$)$. Entities can combine two or more contracts that are entered into at or near the same time with the same customer, and account for them as a single contract, if one or more of the following criteria are met ( $\varepsilon D / 2011 / 6$, par. 17):

- The contracts are negotiated as a package with a single commercial objective.

- The amount of consideration in one contract depends on the price or performance of the other contract.

- The goods or services promised in the contracts are a single performance obligation.

Based on the examination of the terms and conditions of single-company programmes, the contractual rights and obligations to which the revenue recognition model would be applied in the client loyalty programme transaction can be identified. A client loyalty programme transaction may be regarded as a single transaction consisting of two separate identifiable 
components, namely the sale of goods or services, and the granting of points that gives the customer a right to benefits.

There are two contracts that arise in a client loyalty programme transaction. The first contract arises in the initial sales transaction under which the supplier is obligated to supply goods or services in exchange for compensation. A second contract arises under which the supplier is obligated to grant points to the member (customer) that gives the member a right to benefits. The terms and conditions as stipulated in the application form of a client loyalty programme determine the amount of points that will be granted for purchase transactions for a specific value and that these points can be exchanged for benefits during a following purchase transaction. The approval of the signed application form and the issue of a membership card can be seen as an agreement or contract between the supplier and the member (customer). The contract is also implied, as it is the client loyalty programme supplier's practice to grant points on purchase transactions to members and to supply benefits when the member exchanges the points. In terms of the contract, the member therefore has a right to points with each purchase transaction and a right to receive benefits with the exchange of the points. In terms of the contract, the client loyalty programme supplier has an obligation to grant points to members with each purchase transaction and to supply benefits with the exchange of points during a following purchase transaction. A client loyalty programme transaction therefore meets the criteria of two contracts.

If the goods or services promised in the two contracts are a single performance obligation, then the two contracts can be accounted for as a single contract. Refer to 'Step 2: Identify the separate performance obligations in the contract' below for further discussion.

\section{Step 2: Identify the separate performance obligations in the contract}

The aim of the second step is to identify promised goods or services that are distinct and therefore would be accounted for separately (Grant Thornton, 2012:20). The proposed new model requires an entity to evaluate the terms of the contract, and it is customary business practice to identify the promised goods or services that are distinct, and hence, accounted for separately $(\varepsilon D / 2011 / 6$, par. 23$)$. A performance obligation is a promise in a contract with a customer to transfer a good or service, and may be stated explicitly or may be implicit and those promises must create a valid expectation of the customer that the entity will transfer a good or service (ED/2011/6, par. 24).

A good or service is distinct if the entity regularly sells the good or service separately or if the customer can benefit from the good or service on its own or together with other readily available resources $(\varepsilon D / 2011 / 6$, par. 28$)$. A good or service that is part of a bundle of goods or services is not distinct; hence the bundle is accounted for as one performance obligation if the goods or services are highly interrelated and the entity provides a significant service to integrate them into item(s) for which the customer has contracted and the goods or services are significantly modified or customised to fulfil the contract (ED/2011/6, par. 29).

The terms and conditions of the client loyalty programme contract determine that the supplier will supply goods or services in the initial purchase transaction together with points. The contract also determines that when the member exchanges these points the supplier will supply benefits. The promised goods or services under a client loyalty programme transaction consists of the goods or services supplied in the initial purchase transaction as well as the goods or services supplied with the exchange of the points. Each member will have a valid expectation to receive goods or services or a discount on goods or services during a following purchase 
transaction when points are exchanged. It is not only the terms and conditions in the application form (the contract) that create this expectation, but also the fact that it is the client loyalty programme supplier's practice to grant points on purchase transactions to members and to supply benefits when the member exchanges points. The goods or services supplied initially and in exchange for the points are distinct, as the client loyalty programme supplier regularly sells (exchanges) goods or services separately, and the member can benefit from the good or service on its own or together with other readily available resources. The two distinct goods or services in a client loyalty programme transaction can therefore be accounted for as a separate performance obligation.

In order to assist preparers with the application of the proposed new model, Appendix B gives guidance on specific issues and includes a section entitled Customer option for additional goods or services.

\section{Customer option for additional goods or services}

Customer options to acquire additional goods or services for free or at a discount includes points granted in a client loyalty programme transaction ( $E D / 2011 / 6$, par. B20). The revised $\varepsilon D$ states that an option to acquire additional goods or services for free or at a discount would represent a separate performance obligation if it gives the customer a material right that it otherwise would not have received without entering into the contract (ED/2011/6, par. B21). An entity may need to use significant judgement when determining whether this option gives the customer a material right that it otherwise would not have received without entering into the contract (Deloitte, 2012:3). If the option provides a material right to the customer, the customer in effect pays the entity in advance for future goods or services, and the entity recognises revenue when those future goods or services are transferred or when the option expires (ED/2011/6, par. B21).

If a customer has the option to acquire an additional good or service at a price that would reflect the stand-alone selling price for that good or service, that option does not provide the customer with a material right even if the option can be exercised only because of entering into a previous contract. In those cases, the entity has merely made a marketing offer that it shall account for in accordance with the proposed revenue requirements only when the customer exercises the option to purchase the additional goods or services ( $E D / 2011 / 6$, par. B22).

In a client loyalty programme transaction, the member receives an option to receive goods or services or a discount on goods or services in a future purchase transaction. When points are exchanged, the member therefore does not pay a price that reflects the stand-alone selling price for the goods or services received; the member simply exchanges the points previously earned.

If the stand-alone selling price for a customer's option to acquire additional goods or services is not directly observable, an entity shall estimate it. That estimate shall reflect the discount the customer would obtain when exercising the option, adjusted for both of the following: 1) any discount that the customer could receive without exercising the option; and 2) the likelihood that the option will be exercised (ED/2011/6, par. B23).

\section{Step 3: Determine the transaction price}

The transaction price is the amount of consideration that an entity expects to be entitled to in exchange for transferring promised goods or services to a customer and does not include the effects of the customer's credit risk (ED/2011/6, par. 50). 
Factors to consider when determining the transaction price include:

- variable consideration;

- the time value of money;

- non-cash consideration; and

- consideration payable to a customer (ED/2011/6, par. 52).

When considering client loyalty programme transactions, the following is applicable: during the initial purchase transaction the member pays a consideration for goods or services as well as for the points granted. The member in effect pays the supplier for goods and services received in the initial purchase transaction, but this consideration also includes an amount paid in advance for future goods or services. The total amount of consideration paid in the initial transaction is the transaction price for the client loyalty programme transaction. The consideration payable to the supplier is fixed (and not variable) and equal to the selling price (list price) of goods or services purchased in the initial purchase transaction. For all single-company client loyalty programmes investigated, the consideration is immediately payable in cash and therefore the time value of money and non-cash consideration is not applicable.

The client loyalty programme supplier must allocate the total consideration (transaction price) to the goods or services sold and to the points granted (the separate performance obligations) as discussed in Step 4.

\section{Step 4: Allocate the transaction price to the separate performance obligations}

An entity must allocate the transaction price to each of the identified performance obligations based on the relative stand-alone selling prices of the underlying goods and services. The stand-alone selling price is the price at which an entity would sell a promised good or service separately to a customer, for example the list price of the goods or services (ED/201l/6, par. 70-72). If stand-alone selling prices are not directly observable, an entity will need to use estimates, based on reasonably available information. Suitable estimation techniques include the adjusted market assessment approach, expected cost plus a margin approach, and the residual approach (ED/2011/6, par. 73).

In a client loyalty programme transaction consideration is paid for the goods or services supplied in the initial purchase transaction and for the goods or services supplied in a following purchase transaction (in exchange for points granted in the initial transaction). A client loyalty programme supplier will be able to determine the value of the goods or services supplied in the initial purchase transaction (with reference to the list price) as well as the goods or services that will be supplied in the future with reference to the number and corresponding value of the points granted. The problem with allocating these values to the performance obligations is that these values do not equal the consideration received. The value of the goods or services that will be supplied in the future will also be influenced by any discount that the member could receive without exchanging the points, and the likelihood that all the points granted will be exchanged. The client loyalty programme supplier has to use an estimation technique to determine the relative stand-alone selling prices of the underlying goods and services.

$\varepsilon D / 2011 / 6$ paragraph 73 (c) specifies the circumstances in which a residual approach would be a suitable method to estimate a stand-alone selling price:

If the stand-alone selling price of a good or service is highly variable or uncertain, then an entity may estimate the stand-alone selling price by reference to the total transaction price 
less the sum of the observable stand-alone selling prices of other goods or services promised in the contract. A selling price is highly variable when an entity sells the same good or service to different customers (at or near the same time) for a broad range of amounts. A selling price is uncertain when an entity has not yet established a price for a good or service and the good or service has not previously been sold.

In view of the requirement of 'highly variable' provided above, the following is applicable for client loyalty programme transactions: When goods or services are sold to a customer, the same selling price for specific goods or services is asked whether the customer is a member and points are granted or whether the customer is not a member and no points are granted. In a client loyalty programme transaction goods and services together with points are granted to a member for the same price as goods and services (without points granted) supplied to a customer in an ordinary sales transaction. Different goods and services are therefore sold for the same price. It can be concluded that the stand-alone selling price of a client loyalty programme goods or services is highly variable. It is only required that the stand-alone selling price meet one of the above-mentioned requirements and therefore a client loyalty programme supplier can apply the residual approach to estimate the stand-alone selling price of a good or service.

The only reference to client loyalty programme transactions is found in $\varepsilon D / 2011 / 6$ AG, paragraph B20. Paragraphs B20-24 give guidance on the recognition of revenue in transactions where customer options for additional goods or services are present. Paragraph B23 determines that if the stand-alone selling price for a customer's option to acquire additional goods or services is not directly observable, an entity shall estimate it. That estimate shall reflect the discount the customer would obtain when exercising the option, adjusted for both of the following: 1) any discount that the customer could receive without exercising the option; and 2) the likelihood that the option will be exercised (ED/2011/6 AG, par. B23). Using the guidelines in paragraph B23, client loyalty programme suppliers can estimate the stand-alone selling price for the points granted in the initial purchase transaction. The points of all the single-company client loyalty programmes that were investigated have a determinable value. The supplier can therefore determine the stand-alone selling price of the points granted with reference to the rand value linked to the points granted and this value can be adjusted for any discount the member could receive without exchanging the points and also for the number of points expected to be exchanged (refer to 'Illustrative example included in $E D / 2011 / 6$ ' for an illustration of this calculation).

After determining the stand-alone selling price of the points granted, the client loyalty programme supplier can now estimate the stand-alone selling price of the goods or services supplied in the initial purchase transaction by applying paragraph 73 (c) residual approach. The stand-alone selling price of the goods or services supplied in the initial purchase transaction equals the total consideration received (transaction price) less the stand-alone selling price for the points granted (the observable stand-alone selling prices of other goods or services promised in the contract).

\section{Step 5: Recognise revenue when (or as) the entity satisfies a performance obligation}

$\varepsilon D / 2011 / 6$ paragraph 31 states that an entity must recognise revenue when or as it satisfies performance obligations by transferring control of a good or a service (i.e. the asset) to a customer. ED/2011/6 paragraph 32 goes on to explain what is meant by control of an asset and therefore when revenue can be recognised. The entity must also determine if the performance obligations are satisfied over time or at a point in time (ED/2011/6, par. 34). 
In a client loyalty programme transaction the supplier will allocate the total consideration received (transaction price) to the points granted (option to acquire additional goods or services) and to the goods or services initially sold. The client loyalty programme supplier must defer the part of revenue allocated to the points. The consideration allocated to the goods or services initially sold will be recognised as revenue when the transaction takes place, because control is transferred to the customer (member). The deferred revenue will be recognised only when control of the goods or services underlying the points is transferred to the customer or when the points expire. If a customer does not exercise all of its rights under the option at once it will result in 'breakage' of the contract liability (Deloitte, 2012:3). In order to assist preparers with the application of the proposed new model, Appendix B (which is considered to be an integral part of the ED) gives guidance on specific issues and includes a section entitled 'Customers' unexercised rights (breakage)'.

Customers' unexercised rights (breakage)

Upon receipt of a non-refundable prepayment from a customer that gives the customer the right to receive goods or services in the future, the entity shall recognise a contract liability. The entity shall derecognise the contract liability when it satisfies its performance obligation (when it transfers the goods or services) ( $\varepsilon D / 2011 / 6$ par. B25). There is a possibility that the customers do not exercise all of their contractual rights (ED/2011/6 par. B26). If an entity is reasonably assured of being entitled to the amount of expected breakage, the entity will recognise the effects of the expected breakage 'in proportion to the pattern of rights exercised by the customer' ( $\varepsilon D / 2011 / 6$, par. B27). Otherwise, the expected breakage would be recognised 'when the likelihood of the customer exercising its remaining rights becomes remote' (ED/2011/6, par. B27).

In a client loyalty programme transaction it is possible that the points granted during the initial purchase transaction are not all exchanged during a subsequent purchase transaction. If the client loyalty programme supplier accounted for the total points granted during the initial purchase transaction, it will be possible to determine with reasonable assurance when only a portion of the points are exchanged during a following purchase transaction. The client loyalty programme supplier can then recognise a part of the deferred revenue as revenue in proportion to the points exchanged.

It is therefore crucial that entities should have sufficient systems in place to accumulate sufficient historical transaction information in order to recognise the effects of breakage as revenue over time (Deloitte, 2012:5). If a client loyalty programme supplier does not accumulate historical transaction information it will be impossible to identify the total unexercised rights (breakage), and it will not be able to recognise the breakage as revenue until the 'likelihood of the customer's exercising its remaining rights becomes remote' ( $\varepsilon D / 2011 / 6$, par. B27).

\subsection{Comparing IFRIC 13 with ED/2011/6}

TABLE 1 illustrates the similar guidelines contained in IFRIC 13 and in ED/2011/6 specific to a client loyalty programme transaction. 
TABLE 1: Comparing the guidelines of IFRIC 13 and $\varepsilon D / 2011 / 6$

A client loyalty programme transaction is a single transaction consisting of two separate identifiable components. The selling price in a client loyalty programme transaction includes an amount for subsequent servicing (IFRIC 13, par.5, IAS 18, par. 13).
An option to acquire additional goods or services for free or at a discount would represent a separate performance obligation if it gives the customer a material right that it otherwise would not have received without entering into the contract. If the option provides a material right to the customer, the customer in effect pays the entity in advance for future goods or services (ED/2011/6 AG, par. B21).

The consideration received or receivable from the sale should be allocated to the goods or services sold and the points granted. The portion allocated to the goods or services sold will be recognised as revenue during the sales transaction. The portion allocated to the points will be recognised as revenue only when the points are exchanged for benefits, and the recognition of this portion of the revenue is therefore deferred (IFRIC 13, par.5, IAS 18, par. 13, IFRIC 13, par. 7).

If a supplier supplies the benefits itself, it shall recognise the consideration allocated to points as revenue when points are exchanged and the supplier fulfils its obligation to supply benefits. The amount of revenue recognised shall be based on the number of points that have been exchanged for benefits, relative to the total number expected to be exchanged (IFRIC 13, par.7).

An entity must recognise revenue when or as it satisfies performance obligations by transferring control of a good or a service (i.e. the asset) to a customer (ED/2011/6. par. 31).
The fair value of the consideration received under the initial sale must be allocated between the points and the other components of the sale (IFRIC 13 , par. 5).

The portion of consideration allocated to the points granted in the underlying sales transaction shall be measured by reference to their fair value (IFRIC 13, par 6). If there is not a quoted market price for an identical point, fair value must be measured using another valuation technique. The supplier may measure the fair value of points by reference to the fair value of the benefits they could be exchanged for (IFRIC 13, AG par. 1), in other words, the value of the points (held as an asset) in the hands of the consumer. The fair value of the points takes into account, as appropriate:
If a customer does not exercise all of its rights under the option at once it will result in 'breakage' of the contract liability. If an entity is reasonably assured to be entitled to the amount of expected breakage, the entity would recognise the effects of the expected breakage 'in proportion to the pattern of rights exercised by the customer' (ED/2011/6, par. B27).

An entity must allocate the transaction price to each of the identified performance obligations based on the relative stand-alone selling prices of the underlying goods and services. The stand-alone selling price is the price at which an entity would sell a promised good or service separately to a customer, for example the list price of the goods or services (ED/2011/6, par. 70-72).

If the stand-alone selling price for a customer's option to acquire additional goods or services is not directly observable, an entity shall estimate it. That estimate shall reflect the discount the customer would obtain when exercising the option, adjusted for both of the following: 1) any discount that the customer could receive without exercising the option; and 2) the likelihood that the option will be exercised (ED/2011/6 AG, par. B23). 


\footnotetext{
- the amount of the discounts or incentives that would otherwise be offered to consumers who have not earned points from an initial sale;

- the proportion of points that are not expected to be exchanged by consumers; and - non-performance risk (IFRIC 13, AG par. 2).
}

\section{Source: Author's analysis}

TABLE 2 illustrates one difference noted in the guidelines contained in IFRIC 13 and in $\varepsilon D / 2011 / 6$ specific to a client loyalty programme transaction.

Table 2: The difference in the guidelines of IFRIC 13 and ED/2011/6

\begin{tabular}{|c|c|}
\hline IFRIC 13 & $\varepsilon D / 2011 / 6$ \\
\hline $\begin{array}{l}\text { The portion of consideration allocated to the points } \\
\text { granted in the underlying sales transaction shall be } \\
\text { measured by reference to their fair value (IFRIC 13, } \\
\text { par. } 6 \text { ). }\end{array}$ & $\begin{array}{l}\text { An entity must allocate the transaction price to } \\
\text { each of the identified performance obligations } \\
\text { based on the relative stand-alone selling prices of } \\
\text { the underlying goods and services (ED/201l/6, par. } \\
71 \text { ). }\end{array}$ \\
\hline
\end{tabular}

\section{Source: Author's analysis}

A discussion of this difference follows.

\subsubsection{Fair value of consideration received allocated to points by reference to their fair value vs. the transaction price allocated to points based on the relative stand-alone selling prices}

Many IFRSs allow or require the use of fair value without adequate and consistent guidance on how fair value is to be determined. The objective of IFRS 13 Fair Value Measurement (issued 18 May 2011) among other things is to define the term 'fair value'. IFRS 13 applies when another IFRS requires or permits fair value measurement (IFRS 13, paragraph 5) and consequently applies to IFRIC 13.

IFRS 13 defines fair value as 'the price that would be received to sell an asset ... in an orderly transaction between market participants at measurement date' (IFRS 13, par. 9). The transaction price is the amount of consideration that an entity expects to be entitled to in exchange for transferring promised goods or services to a customer ( $E D / 2011 / 6$, par. 50$)$. The fair value referred to in IFRIC 13 (the price that would be received) and the transaction price (the consideration that an entity expects to be entitled to) referred to in ED/2011/6 come down to the same thing.

The difference in the accounting treatment of a client loyalty programme transaction under IFRIC 13 and under the proposed new model is found in the allocation of the fair value (IFRIC 13) or the transaction price $(\varepsilon D / 2011 / 6)$ to the goods or services sold in the initial transaction and the points granted (performance obligations). 
The requirement in $\varepsilon D / 2011 / 6$ that the allocation of the transaction price should be based on the relative stand-alone selling prices causes the difference. The stand-alone selling price is the price at which an entity would sell a promised good or service separately to a customer, for example the list price of the goods or services (ED/2011/6, par. 70-72). The stand-alone selling price of $\varepsilon D / 2011 / 6$ is in correlation with the fair value under IFRIC 13 that must be allocated to the points, i.e. the fair value of the benefits they could be exchanged for (IFRIC 13, AG par. 1), in other words, the value of the points (held as an asset) in the hands of the customer. By adding the word 'relative' to stand-alone selling price, the calculation of the value allocated to the points granted changes.

To illustrate the difference between the accounting treatment of a single-company client loyalty programme transaction, the information of the illustrative example that accompanies $\varepsilon D / 2011 / 6$ was processed using the IFRIC 13 guidelines and processed using the guidelines of the proposed new model.

\subsection{Illustrative example included in ED/2011/6}

$\varepsilon D / 2011 / 6$ includes examples to illustrate the guidance given. Example 24 illustrates the requirements in paragraph $B 23(\varepsilon D / 2011 / 6 \mathrm{AG})$ on determining the amount of the transaction price to allocate to an option as part of a customer loyalty programme. Only one example that specifically applies to client loyalty programme transactions is included in $E D / 2011 / 6$ (vs. the two illustrative examples that accompany IFRIC 13). This example's given information or scenario is similar to that of the first illustrative example that accompanies IFRIC 13. Given that only one illustrative example on client loyalty programme transactions is included in $\varepsilon D / 2011 / 6$, Deloitte (2012:3) is of the opinion that the boards may need to further clarify the guidance in drafting the final standard to ensure that it is applied consistently. The scenario in the illustrative example is as follows:

An entity has a customer loyalty programme that rewards a customer with one customer loyalty point for every CU10 of purchases. Each point is redeemable for a CUI discount on any future purchases. During a reporting period, customers purchase goods or services for CU100 000 and earn 10000 points redeemable for future purchases. The stand-alone selling price of the purchased goods or services is CU100000. The entity expects 9500 points to be redeemed on the basis of its past experience that it concludes is predictive of the amount of consideration to which it will be entitled. The entity estimates a stand-alone selling price of CU0.95 per point (or CU9 500 total) on the basis of the likelihood of redemption. The points provide a material right to customers that they would not receive without entering into a contract. Hence, the entity concludes that the points are a separate performance obligation.

The entity allocates the transaction price to the goods or services and the points on a relative stand-alone selling price basis as follows: CU91 324 is allocated to the goods or services sold (CU100 $000 \times$ CU100 $000 \div$ CU109 500) and CU8 676 is allocated to the points granted (CU100 000 $\times$ CU9 $500 \div$ CU109 500). At the end of the first reporting period, 4500 of the points have been redeemed and the entity continues to expect 9500 points to be redeemed in total. The entity recognises revenue for the points of CU4 110 [(4 500 points $\div 9500$ points $) \times$ CU8 676]. See the journal entries in year one in TABLE 3. During the second reporting period, an additional 4000 points are redeemed (cumulative points redeemed are 8500 ). The entity expects that 9700 points will be redeemed in total. The cumulative revenue that the entity recognises is CU7 603 [ $(8500 \div 9700) \times$ CU8 676]. The entity has recognised CU4 110 in the first reporting period, so it recognises revenue for the points of CU3 493 (CU7 603 - CU4 110) in the second reporting period. 
See the journal entries in year two in TABLE 3. In the third reporting period, an additional 1200 points are redeemed (cumulative points redeemed are 9700 ). The entity expects that no additional points will be redeemed. The entity has already recognised revenue of CU7 603, so it recognises the remaining revenue for the points of CU1 073 (CU8 676 - CU7 603) (ED/2011/6 Illustrative examples, Example 24). See the journal entries in year three in TABLE 3.

The journal entries in TABLE 3 below are based on the guidance in ED2011/6 and illustrate the accounting entries of the transaction described above in the general journal of the client loyalty programme supplier.

TABLE 3: General journal entries of the client loyalty programme supplier

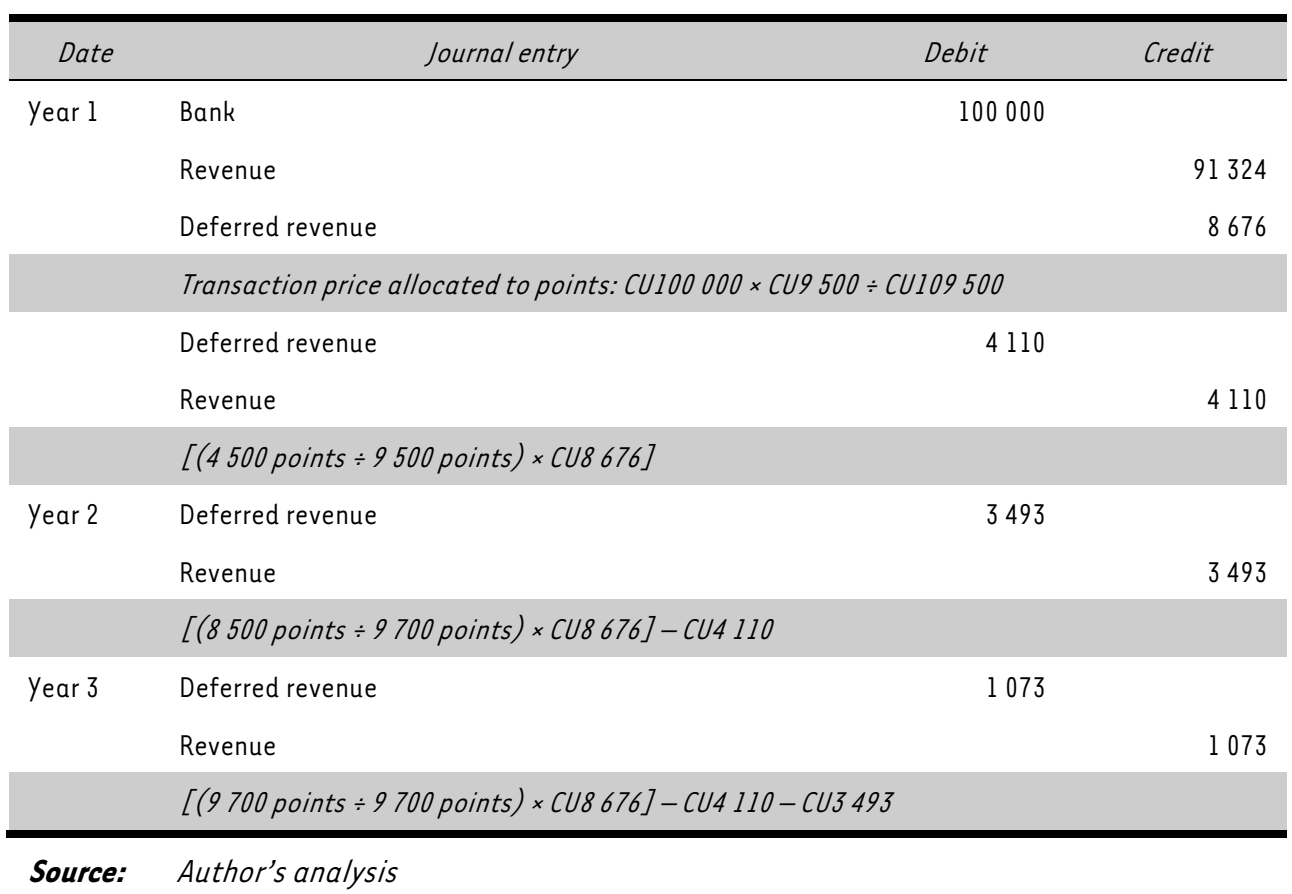

\subsection{Differences noted from IFRIC 13}

TABLE 4 illustrates the accounting entries of the transaction described above if IFRIC 13 is applied to the same scenario.

The only difference in the accounting treatment of a client loyalty programme transaction under IFRIC 13 and under the proposed new model is the calculation of the value allocated to the points and to the goods or services supplied in the initial purchase transaction.

The example included in $\varepsilon D / 2011 / 6$ illustrates how the value allocated to the points should be calculated. The value allocated to points under the proposed new model equals the transaction price multiplied by the stand-alone selling price of the points granted divided by the sum of the stand-alone selling price of the goods or services supplied in the initial purchase transaction and the stand-alone selling price of the points granted (relative stand-alone selling price). 
The value allocated to points under IFRIC 13 equals the fair value of the points multiplied by the expected redemption rate (fair value). The recognition of the deferred revenue with the exchange of points and the change in expected redemption rate is treated the same under IFRIC 13 and under the proposed new model. The effect of the proposed new model is an acceleration of revenue recognition.

TABLE 4: General journal entries of the client loyalty programme supplier

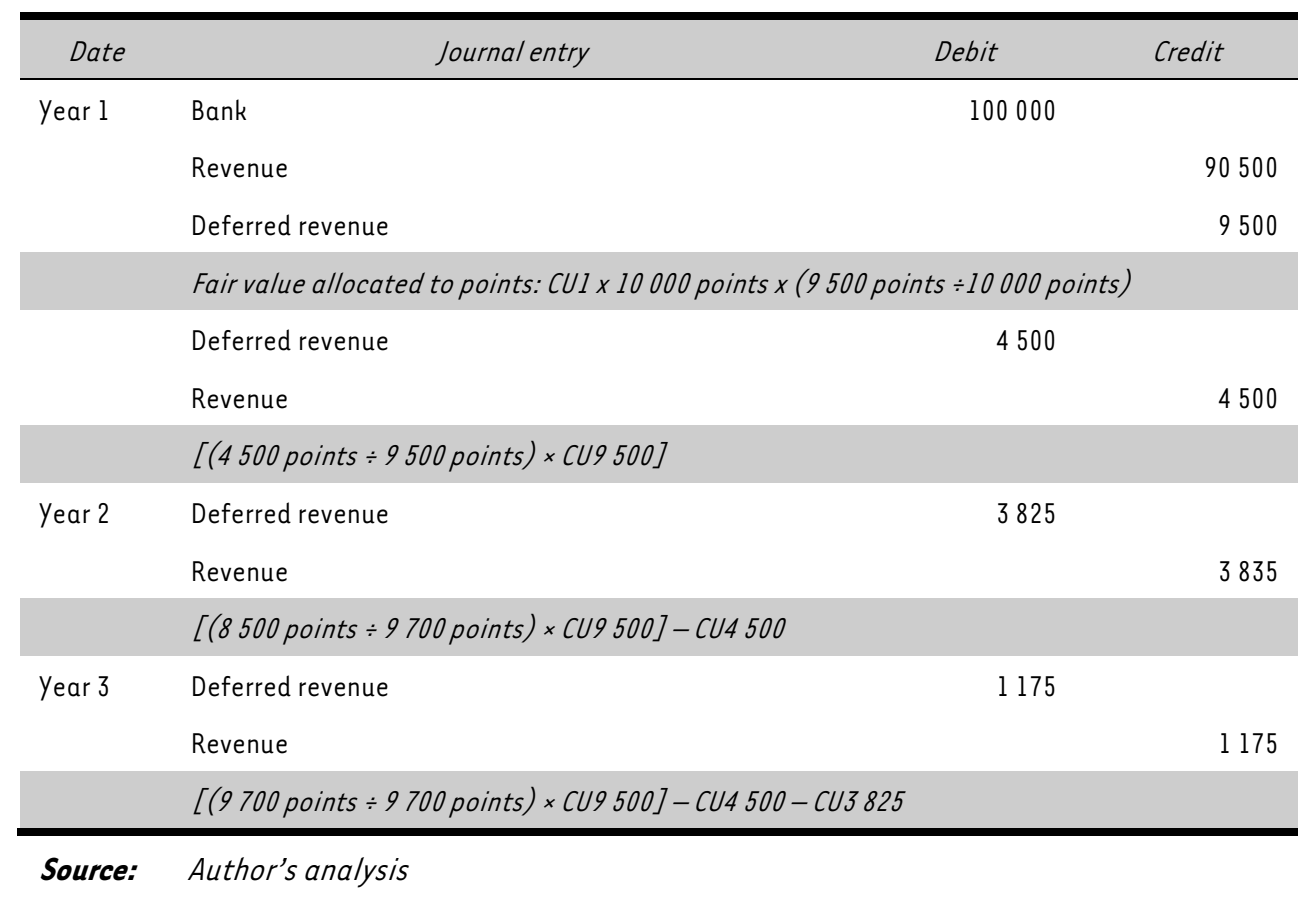

\subsection{Presentation}

$\varepsilon D / 2011 / 06$ paragraph 105 states that the entity must recognise a contract liability in the statement of financial position if a customer pays consideration before an entity performs by transferring a good or service. In a client loyalty programme transaction, the consideration paid by the customer includes an amount for the points granted. Only when the points are exchanged during a subsequent purchase transaction will the supplier supply the goods and services. Under the proposed new model the presentation of the liability for the points granted prior to redemption will therefore become part of a contract liability whereas it is currently presented as deferred revenue (KPMG, 2011:37).

\subsection{Disclosure}

The proposed new revenue standard also requires entities to disclose more information about revenue. A few examples of additional disclosure requirements applicable to client loyalty programme transactions are provided below.

ED/2011/6 paragraph 118 requires the following information to be disclosed about its performance obligations in contracts with customers, including among other things a 
description of when the entity typically satisfies its performance obligations (for example, when points are exchanged and benefits are supplied). The points of some of the single-company client loyalty programmes investigated are not subject to an expiry date. The expected duration of these client loyalty programme transactions (contracts) can therefore exceed one year. $\varepsilon D / 2011 / 6$ paragraph 119 requires that the following information be disclosed for contracts with an original expected duration of more than one year: the aggregate amount of the transaction price allocated to remaining performance obligations and an explanation of when the entity expects to recognise that amount as revenue. ED/2011/6 paragraph 124 requires additional disclosure relating to significant judgement used in the application of the new model, namely disclosing the judgements, and changes in the judgements, made in applying this model that significantly affect the determination of the amount and timing of revenue from contracts with customers. At a minimum, an entity shall explain the judgements, and changes in the judgements, used in determining both of the following: the timing of satisfaction of performance obligations and the transaction price and the amounts allocated to performance obligations.

$\varepsilon D / 2011 / 6$ paragraph 125 requires additional disclosure relating to determining the timing of satisfaction of performance obligations. For performance obligations that an entity satisfies over time, an entity shall disclose both of the following: the methods used to recognise revenue and an explanation of why such methods are a faithful depiction of the transfer of goods or services. For performance obligations satisfied at a point in time, an entity shall disclose the significant judgements made in evaluating when the customer obtains control of promised goods or services ( $\varepsilon D / 2011 / 6$, par. 26$)$.

$\varepsilon D / 2011 / 6$ paragraph 127 requires additional disclosure relating to determining the transaction price and the amounts allocated to performance obligations. An entity shall disclose information about the methods, inputs and assumptions used to: determine the transaction price; estimate stand-alone selling prices of promised goods or services; measure obligations for returns, refunds and other similar obligations and measure the amount of the liability recognised for onerous performance obligations.

\section{CONCLUSION AND RECOMMENDATIONS}

The proposed new revenue standard will replace IFRIC 13 Customer Loyalty Programmes, an interpretation that has been applied by client loyalty programme suppliers since 2008 (annual periods beginning on or after 1 July 2008). It is expected that for annual reporting periods beginning on or after 1 January 2017 all client loyalty programme suppliers will apply the new revenue standard retrospectively for all periods presented in the period to account for the client loyalty programme transactions. The new revenue standard - as opposed to IFRIC 13 - is not only applicable to client loyalty programme transactions but will be applied to account for all revenue transactions. At first the proposed new model may seem overwhelming (the $\varepsilon D$ consists of 89 pages and is not specific to client loyalty programme transactions) to client loyalty programme suppliers, but this article has highlighted the paragraphs specifically applicable to the accounting treatment of client loyalty programme transactions.

It was found that although different terms are used in IFRIC 13 and the proposed new model there is only one difference in the accounting treatment of a client loyalty programme transaction. The difference in the accounting treatment of a client loyalty programme transaction under IFRIC 13 and under the proposed new model is found in the allocation of the 
fair value (IFRIC 13) or the transaction price (ED/2011/6) to the goods or services sold in the initial transaction and the points granted (performance obligations). Under IFRIC 13 the fair value of the consideration received is allocated to the goods or services and to the points granted. The value allocated to the points is calculated with reference to the fair value of the benefits they could be exchanged for (the fair value of the points adjusted for any discounts that would otherwise be offered to customers who have not earned points from an initial sale, the expected redemption rate and non-performance risk) and the balance is allocated to the goods or services supplied.

Under the proposed new model the transaction price (consideration received) is allocated to the goods or services and to the points granted (the identified performance obligations) based on the relative stand-alone selling prices of the underlying goods and services. The stand-alone selling price of the points granted can first be calculated (with reference to the rand value linked to the points granted and this value can be adjusted for any discount the member could receive without exchanging the points and also for the number of points expected to be exchanged) and the balance can be allocated to the goods or services supplied in the initial purchase transaction applying the residual approach.

The effect of the proposed new model on the accounting treatment of a single-company client loyalty programme transaction is that less revenue will initially be deferred and this will result in an acceleration of revenue recognition. The presentation of the liability for the points granted and not exchanged will no longer be presented as deferred revenue (as per IFRIC 13) in the statement of financial position, but under the proposed new model as a contract liability (KPMG, 2011:37). The proposed new revenue standard also requires entities to disclose more information about revenue and therefore about client loyalty programme transactions.

All client loyalty programme suppliers should familiarise themselves with the proposed new revenue standard and be aware of the impact of this standard on client loyalty programme transactions. It is crucial for client loyalty programme suppliers to start collecting data for the retrospective application of the new standard (Lamoreaux, 2012:30). Even though the effective date of the new revenue standard was moved to 1 January 2017, points or miles (not subject to an expiry date) granted today can still have an impact on reporting in 2017.

This article provides client loyalty programme suppliers with the necessary knowledge regarding the proposed new model, which means that they do not have to examine the comprehensive $\varepsilon D / 2011 / 6$, which consists of 89 pages (excluding the illustrative examples and the basis for conclusion).

\section{LIST OF REFERENCES}

Conradie, B. (bruce@worldwideworx.com). 17 June 2011. RE: Bruce Conradie. Email to author.

Conradie, B. (2007). Value in loyalty programmes 2007: A survey of South African rewards-based loyalty programmes. Razor's Edge Business Intelligence.

Deloitte. (2012). Retail \& Distribution Spotlight: How the Converged Revenue Recognition Model May Affect Sales Targets. [Online] Available: http://www.deloitte.com/assets/DcomUnitedStates/Local\%20Assets/Documents/AERS/ASC/us_aers_RDspotlight_0611.pdf. (Accessed 5 June 2012). 
ED/2011/6, Revenue from contracts with customers. (2011). International Accounting Standards Board (IASB). London.

Ernst \& Young. (2011). IASB and FASB revised revenue recognition proposa/s. [Online] Available: http://www.ey.com/Publication/vwLUAssets/IFRS_Development_Issue_18/\$FIE/IFRS\%20Developme nts\%201ssue\%2018_1111.pdf. (Accessed 5 June 2012).

Ernst \& Young. (2012a). Revenue from contracts with customers - the revised proposal. [Online] Available:

http://www.ey.com/Publication/vwLUAssets/Applying_IFRS_Revenue_from_contracts_with_custom ers/\$FILE/Applying_IFRS_Revenue_from_contracts_with_customers.pdf. (Accessed 5 June 2012).

Ernst \& Young. (2012b). The revised revenue recognition proposal - retail and consumer products. [Online] Available:

http://www.ey.com/Publication/vwLUAssets/Applying_IFRS_in_Retail_and_Consumer_Products/\$FI LE/Applying\%20IFRS\%20\%20Revenue\%20recognition\%20proposal_retail\%20and\%20consumer\%20pr oducts.pdf. (Accessed 5 June 2012).

Ernst \& Young. (2013). Boards revisit disclosure, transition and effective date in the revenue project. [Online] Available: http://www.ey.com/Publication/vwLUAssets/IFRS_Developments-

Issue_52/\$FILE/Devel52_Revenue_Feb_2013.pdf. (Accessed 30 July 2013)

Grant Thornton. (2012). Impact of Revised Revenue Recognition Proposal on Construction, Real Estate and Hospitality Companies, [Online] Available:

http://www.grantthornton.com/staticfiles/GTCom/Calendar\%200f\%20Events/Archived\%20webcasts /2012\%20Archived\%20webcast\%20slides/Impact_of_Revised_Rev_Rec_on_CRH.pdf. (Accessed 5 June 2012).

IAS 18, Revenue. (1993). International Accounting Standards Board (IASB). London. IASB. (2014). Workplan for IFRSs. [Online] Available: http://www.ifrs.org/Current-Projects/IASB-

Projects/Pages/IASB-Work-Plan.aspx. (Accessed 13 February 2014)

IFRIC 13, Customer Loyalty Programmes. (2007). International Accounting Standards Board (IASB). London.

IFRS 13, Fair Value Measurement. (2011). International Accounting Standards Board (IASB). London. IFRS. (2011). Revenue from Contracts with Customers. [Online] Available:

http://www.ifrs.org/Current-Projects/IASB-Projects/RevenueRecognition/ EDNov11/Documents/RevRec_EDII_Standard.pdf. (Accessed 5 June 2012).

KPMG. (2011). New on the horizon: Revenue from contracts with customers. [Online] Available: http://www.kpmg.com/Global/en/IssuesAndInsights/ArticlesPublications/New-on-theHorizon/Documents/NOTH-revenue-from-contracts-a.pdf. (Accessed 19 0ctober 2012).

Lamoreaux, M.G. (2012). A new system for recognizing revenue. Journal of accountancy 213.1 (Jan 2012): $30-35,10$.

Liu, Y. (2007). The long-term impact of loyalty programmes on consumer purchase behaviour and loyalty. Journal of Marketing. [Online] Available:

http://web.ebscohost.com.ez.sun.ac.za/ehost/pdfviewer/pdfviewer?sid=eb9lde90-b5da-4e0fbb71-4a9965cla313\%40sessionmgrl 1\&vid=5\&hid=17. (Accessed 19 April 2011)

Maharaj, A. (2008). Awareness perceptions and effects of customer loyalty programmes within the retail sector of the Durban Metropolitan area. Unpublished Master's dissertation. Pretoria: University of South Africa. 
Marcy, S. (2012). FASB, IASB Gain acceptance on revenue recognition direction. Accounting Policy \& Practice Report, 8.3 (Jun 22, 2012), pp. 535-536.

Republic of South Africa. (2008). Consumer Protection Act No.68 of 2008. Cape Town: Government Gazette 526 (32186), pp. 1-94.

Seghposs, D. (2013). FASB and IASB Set Effective Date for New Revenue Recognition Standard.

[Online] Available: https://blogs.oracle.com/FinancialsMkting/entry/fasb_and_iasb_set_effective. (Accessed 30 July 2013)

Travel wires. (2011). Terms and conditions distort loyalty programmes - Protea Hospitality.

[Online]Available: http://www.travelwires.com/wp/2011/03/\%E2\%80\%9Cterms-

conditions\%ع2\%80\%9D-distort/. (Accessed 8 April 2011). 
